\title{
THE POTENTIAL OF LAMPUNG LOCAL SAND AS CASTING SAND IN THE METAL CASTING PROCESS
}

\author{
David C Birawidha1 ${ }^{1}$ Kusno Isnugroho1, Yusup Hendronursito ${ }^{1 *}$, Fathan Bahfie ${ }^{1}$, \\ Wulanda Y.P ${ }^{2}$, Sapriyadi ${ }^{2}$ \\ ${ }^{1}$ Research Unit for Mineral Technology- LIPI \\ JI.Ir.Sutami Km 15, Tanjung Bintang, Lampung Selatan, Lampung \\ 2University of Lampung \\ JI. Prof. Dr. Sumantri Brojonegoro No. 1 Bandar Lampung, 35145, Indonesia \\ e-mail: yusu016@lipi.go.id
}

Diterima: 21 Januari 2019; Direvisi: 21 Januari 2019 - 24 Juli 2019; Disetujui: 30 Juli 2019

\begin{abstract}
In Indonesia especially sumatra island, the demands for casting sand was mainly fulfilled using sand brought from ceper, central Java although with a very expensive transportation cost. For the Sumatran region, the province of Lampung is rich in quartz sand that has the potential to act as substitute to the Java originated sand. This experiment aims to characterize sand from sub district Tanjung Bintang and sub district Maringgai of Lampung province as reference for its use as casting sand. In this experiment, two kinds of sand sample extracted from Lampung province were characterized using X-RF and X-RD. Casting sand from Ceper of Middle Java province was analyzed as comparison. The results showed that although the water and clay contents of Ceper sand were higher than that of Lampung sand, the Lampung sand itself had finer particle size and morphology which were shown by higher Grain Finenesss Numbers (GFNs) than Ceper casting sand, at 48.49 for Tanjung Bintang sand and 47.61 for Maringgai sand as opposed to Ceper's 31.31. With higher GFNs value, chance of surface defect can be minimalize. Elemental analyses showed that Lampung sand contained more $\mathrm{Al}_{2} \mathrm{O}_{3}$ and $\mathrm{MgO}$ than its Java counterpart. For Tanjung Bintang sand have $\mathrm{Al}_{2} \mathrm{O}_{3}$ content at $13.87 \%$ and $18.76 \%$ for Maringgai sand respectively. For Ceper sand only have $4.54 \%$ for $\mathrm{Al}_{2} \mathrm{O}_{3}$ and for $\mathrm{MgO}$, only Maringgai sand which contain it at $1.39 \%$. These elements contribute to the improvement of the ability of produced casting sand to resist higher temperature and reducing the need for binder material.
\end{abstract}

Keywords : casting sand, characterization, Ceper sand, Lampung sand, metal casting

\section{INTRODUCTION}

Although there are many new advanced technologies for metal casting, sand casting remains one of the most widely used casting processes today due to the low cost of raw materials, a wide variety of castings with respect to size and composition, and the possibility of recycling the molding sand. The sand casting process is one of the most versatile processes in manufacturing because it is used for most metals and alloys with high melting temperatures such as iron, copper, and nickel. The sand casting process consists of pouring molten metal into a sand mold, allowing the metal to solidify, and then breaking away the sand mold to remove a casting product [Weiss, 2018]. The casting product can then be machined to remove surface imperfections or to add new features by standard machining methods such as grinding, turning, milling, and polishing [Saikaew C and Wiengwiset S, 2012]. Usually, casting sand used in the metal casting process is green sand mixed with additional binding materials such as kaolin and bentonite [Carnin et al, 2012]. In conventional casting, the casting sand used in metal casting must have adequately high product specifications like have form ability, good permeability and is easy to produce. The casting sand production process was made simpler with short production time, it was done by only mixing sand and organic binder in molding cast made of wood [Meng $Y$ and Thomaas, 2003; Simsir M. et al, 2009; Saridikmen H and Kuskonmaz N, 2005; Jiang J and Lin $X, 2007]$. Sand used for metal casting belongs to quartz sand category which is 
abundant in Lampung, Indonesia. Aproximately for quartz sand deposit in Lampung reach 76 million tons [Kusdiarto MS et al, 2019]. The promising quartz sand deposits, especially in Labuhan Maringgai and Pasir Sakti sub districts of East Lampung district, shows higher silica content compared to quartz sand from other regions outside east Lampung [Mulyo A, 2007]. The sand commonly used for casting originated from mountain sand, coastal sand, river sand, and mined silica sand, both natural and artificial silica sand such as quartzite, with particle size of 0.1 $\mathrm{mm}$ to $1.0 \mathrm{~mm}$. To qualify for usage as casting sand, the collected sand must meet criteria such as minimum clay content between 10\% and 20\%, Grain Fineness Numbers (GFNs) values between 40 and 220, and water content between $2 \%$ and $12 \%$ [Lavin P, 2003].

The metal casting process in Lampung province currently uses casting sand from Ceper of Klaten district, Middle Java Province. Meanwhile, quartz sand from Lampung itself although has the potential to use as casting sand has yet to be utilized. Therefore, this study aims to study the characteristics of Lampung quartz sand to explore its potential as casting sand alternative material for metal casting process, especially Lampung's aluminum casting because the characteristics of Lampung sand have resemblance with Ceper sand.

\section{RESEARCH METHOD}

Three types of quartz sand (coded as $A, B$, and $C$ ) were characterized to find out its clay and water contents with weight difference method. ASTM D 2216-10 was used for determining water content of quartz sand where is required driying process of the material sample using oven for several hours. While ASTM D 2419 was used for determining the clay content, where the sample of fine aggregate is mixed with a flocculating solution in a graduated cylinder and is agitated and then allowed to settle. The sand then separates from the flocculated clay particles and the heights of clay and sand in the cylinder are measured. The sand equivalent value is the ratio of the sand height to the clay height, expressed as a percentage [11]. Sand A which came from Ceper was the standard sample of this experiment. While sand $B$ and $C$ were local sand from Lampung province region.

To measure the GFNs (Grain Fineness Numbers) values, all three sand types were sieved with sieve shakers (W.S Tyler model $R x=812-3$, serial 19-1170) and analyzed using macro-photography with 100x zooming to observe the form and size of particles using Nikon optic microscope. X-Ray Fluorescence (XRF) and X-Ray Powder Diffraction (XRD) tests were conducted using Phillips PW 2400 Xray Spectrometer and X-pert MPD model PW 3040 Phillips respectively to analyze the elemental composition and phase. The $X-R F$ process begins with grinding samples until it reaches a size of 100 mesh. Then the sample is formed using a hydraulic tablet press. Samples are heated at temperatures of $1000^{\circ} \mathrm{C}$ in the crucible. Furthermore, the sample is analyzed based on the identification and enumeration of characters of X-rays caused by the photoelectric effect. The photoelectric effect occurs because of the electrons in the target atom in the sample exposed to high-energy rays (gamma radiation, X-rays). As a result of the sample exposed to X-ray radiation, the electron vacancy occurs, while the electrons originating from the skin surface samples will fall to fill the vacancy. X-RF will use $X$-rays emitted by the material and arrested detector to be used to analyze the content of the element in the sample. For X-RD test, begins with grinding the sample, to a fine powder to minimize inducing extra strain (surface energy) that can offset peak positions, and to randomize orientation. powder less than $\sim 10 \mu \mathrm{m}$ (or 200-mesh). Then the powder was placed into a sample holder, smear uniformly onto a glass slide, assuring a flat upper surface. Later, for collecting a diffractogram, the computer automates the data collection and data reduction steps of 
the analysis. The output from the program consists of a plot that lists the location and intensity of the various diffraction peaks that were found in the raw data [Moore $D$ M and Reynolds R C, 1997].

\section{RESULT AND DISCUSSION}

Table 1. Results of water and clay content tests for each sand casting

\begin{tabular}{llll}
\hline Test result & $\begin{array}{l}\text { Sand } \\
(\mathrm{A})\end{array}$ & $\begin{array}{l}\text { Sand } \\
(\mathrm{B})\end{array}$ & $\begin{array}{l}\text { Sand } \\
(\mathrm{C})\end{array}$ \\
\hline $\begin{array}{l}\text { Water } \\
\text { content } \\
\text { average (\%) }\end{array}$ & 1,16 & $\begin{array}{l}0,13 \\
5\end{array}$ & 0,28 \\
& & & \\
$\begin{array}{l}\text { Clay content } \\
\text { average (\%) }\end{array}$ & $\begin{array}{l}35,3 \\
7\end{array}$ & 3,03 & 8,12 \\
\end{tabular}

Sand $\mathrm{A}$ also had the highest clay content at $35.37 \%$ followed by sand $C$ at $8.12 \%$ and $B$ at $3.05 \%$. Based on the standard criteria of casting sand which is later will be used in the mixture sand casting, the water content should be between $2 \%$ and $12 \%$ and clay content should be between $10 \%$ and $20 \%$ [Agarwal $R$ et al, 1981]. While sand A (Ceper sand) had higher water content compared to sand $B$ and $C$ (local sand), its clay content was too high. So usually in its actual use in sand casting, it only need to be added water with the intention to reduce clay content inside sand which is to reach generally $10 \%$ of total water content. The differrent of water and clay content for each sand casting is influenced by the size of sand particle. More course the size more larger the surface area to hold more water and clay. Based on water and clay content analysis (Table 1) and Agarwal et.al [Agarwal $R$ et al, 1981], both local sand types have the potential to be utilize as casting sand and obtained data can be used as references to refine the water and clay content in local sand in order to meet casting sand standards [Agarwal $\mathrm{R}$ et al, 1981]. With adequate clay content in the

\section{Characterization of water and clay content of quartz sand}

Experimental results of water content analysis (Table 1) shows that sand A (Ceper sand) had the highest water content at $1.16 \%$, while Lampung local sand had lower water content at $0.135 \%$ for sand $B$ and $0.28 \%$ for sand $C$.

casting sand, the permeability properties of the casting sand can be maintained to ensure the flow of trapped air from the casting. When the layer of mold sand casting have enough porous because of high permeability, the air which occur during the pouring process can flowed through the pores in sand casting. While suitable water content will support the formability and prevent crack caused by thermal shock. These factor are crucial, because casting sand with lower than optimal water content will also have poor green compression strength value. For a standard casting sand mixture, the minimum green compression strength should be at $1.5 \mathrm{psi}(10.34 \mathrm{kPa})$ [Heine $\mathrm{R}$ et al, 1967]. Low green compression strength will cause defects in the casting result. This is caused by of erosion, collapse, and damage in the inside wall of the casting mold produced with lowstrength casting sand. These problems will produce fine cracks, sand intrusion, imperfectness in casting form, and rough surface in the resulting casting products [Heine R et al, 1967; Brown J, 1994; Ihom A et al, 2009; Zrimsek A and Vinjas G, 1961]. The increase of water content in the casting sand correlates linearly to the increase of green compression strength value of casting sand until it reaches optimal point where a higher water content in the casting sand will result in the decrease the green compression strength[Heine $\mathrm{R}$ et al, 1967; Ihom A et al, 2011; Ihom A et al, 2012]. This condition was also found in the clay content observation of casting sand, where increasing clay content in casting sand correlates linearly to increasing green compression strength [Ihom A et al, 2011; Ihom A et al, 2012]. However, excessive 
clay content in casting sand will reduce permeability property of casting to flow trapped air in the casting. From standard criteria for clay content, it should between $10 \%$ and $20 \%$ and not set at exact number because the optimum clay content will depend on the shape and morphology of the cast object. Based on Abichou, T et al, clay content as binder at sand casting mixture when added water, the clay will start actively binding the grains of sand and spreads closing the pores which formed between the grain of sand [Abichou $\mathrm{T}$ et al, 2002]. This is what causes the permeability of the mold become reduced.

\section{Characterization of grain fineness number (GFN) of quartz sand}

Grain Fineness Number (GFNs) is used as a reference to better understand the size of particles composing the sand and their distribution. A higher GFNs value indicates smaller sand particle size. At casting process, with higher GFNs can influence the surface morphology of cast object, the cavity surface of the casting (the inside part of casting which is in contact with liquid metal) will be smoother, it don't need more machining process.
Experimental measurements of GFNs values (Table 2) revealed that sand $B$ had the highest GFNs values of 48.9 which was a little higher than that of sand $C$ with 47.61 in value. Meanwhile, sand $A$ had the lowest GFNs value at 31.31 compared to the two local sands. The difference of GFNs value for each sample were influenced by the particle distribution in each shieve shaker to measure the GFNs value. More higher GFNs value, the particle size of sand casting more fine. The distribution of fine particle in sample $B$ is more than sample $C$, it started from mesh 40 the particle distribution in each shieve almost the same which result in the value is not much different. According to R.L. Agarwal et.al. (1981), the ideal GFNs value for casting sand is between 40 and 220 [Agarwal R L et al, 1981]. However, according to Akuan (2010), medium and small aluminum casting industries could used sand for casting with GFNs value below 140 [Akuan $A, 2010]$. With these information as reference, local sand $B$ and $C$ with GFNs value higher than the lower limit of ideal GFNs value have the potential to be utilized as material for casting sand. There are four type of sand grain seen in foundry. They are rounded, angular, sub-angular and compounded.

Table 2. Grain Fineness Number (GFN) sand sample

\begin{tabular}{|c|c|c|c|c|c|c|c|c|}
\hline \multirow[t]{2}{*}{ No. } & \multirow[t]{2}{*}{ Mesh } & \multirow[t]{2}{*}{ Sn } & \multicolumn{2}{|c|}{$\begin{array}{c}\text { Ceper sand } \\
\text { (A) }\end{array}$} & \multicolumn{2}{|c|}{$\begin{array}{l}\text { Tanjung Bintang } \\
\text { sand (B) }\end{array}$} & \multicolumn{2}{|c|}{$\begin{array}{l}\text { Maringgai sand } \\
\text { (C) }\end{array}$} \\
\hline & & & $\%$ & Wn.Sn & $\%$ & Wn.Sn & $\%$ & Wn.Sn \\
\hline 1. & $<20$ & 9,6 & 17,60 & 168,96 & 6,78 & 65,08 & 0,11 & 1,05 \\
\hline 2. & 20 & 21,9 & 39,60 & 61,50 & 19,50 & 427,05 & 19,08 & 417,85 \\
\hline 3. & 40 & 45 & 24,17 & 1087,65 & 55,134 & 2490,30 & 64,85 & 2918,25 \\
\hline 4. & 60 & 77,04 & 9,93 & 765,00 & 8,25 & 635,58 & 10,69 & 823,55 \\
\hline 5. & 80 & 109,01 & 2,14 & 233,28 & 2,08 & 226,74 & 1,94 & 211,47 \\
\hline 6. & 100 & 126 & 6,44 & 811,44 & 7,93 & 999,18 & 2,95 & 371,70 \\
\hline
\end{tabular}




\begin{tabular}{lllllll}
\hline Total & 99,88 & 3127,83 & 99,88 & 4843,93 & 99,62 & 4743,87 \\
GFN & 31,31 & & 48,49 & & 47,61 &
\end{tabular}

Generally, rounded grains have the least amount of contact between grains, require the least amount of bonding material and have the greatest flowability [Sudia T and Chijiwa K, 1982]. They have lower strenghts and good venting properties. Rounded sand is often used for cores. Angular grains have good permeability, because of the interlocking nature of the angular grains, they resist compaction. Angular grains have smaller surface contact, so the permeabilty to flowed the air more higher. Fine angular sand is often used in aluminium foundries for good surface finish because of its good permeability. Angular grains require more work to coat with clay because the clay does not smear from grain to grain as easily. The shape of angular grain was not roundabout like roundes grains shape. So more clay to bonding between grain is needed. Beside this two, there are another type sand grain which is known as compound sand. However the compounded sand grains may break down under the heat of the metal pouring causing a build up of fines and unpredictable molding properties. The structure of compound grained sand is formed when two or more sand grains stick together and don't separate either on sawing or washing. This form result in unstable bonding in sand casting mixture when heat was applied [Bawa H S, 2004]. Compound grains are less desirable and should be avoioded [Chastain S D, 2003].

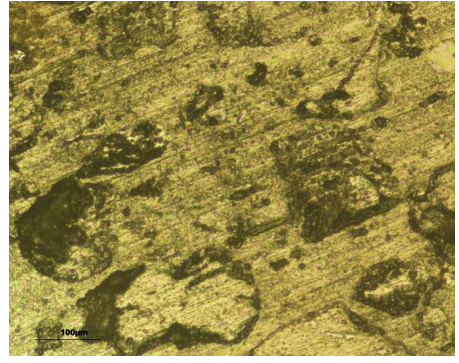

Figure 1. Sand A,

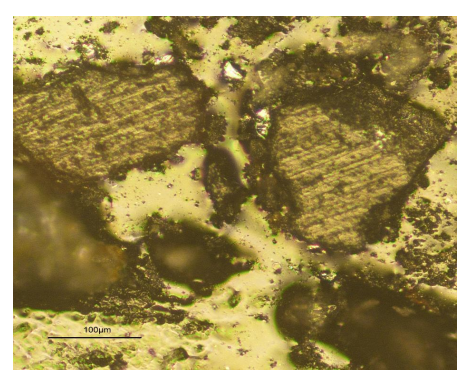

Figure 2. Sand B

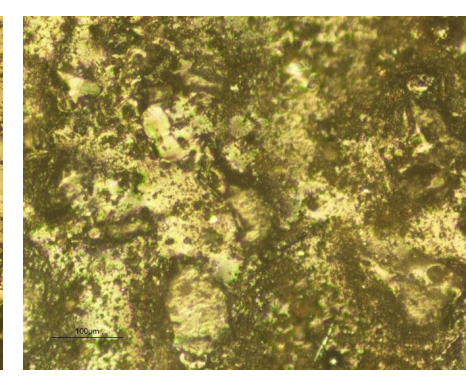

Figure 3. Sand C macro image
The experimental result for particles distribution (Figure 1 to 3 ) revealed that sand A was composed mostly of roundedged particles and only a few of them were sharp-edged-angular particles. With larger distribution of round-edged particles will contribute to a better performance of the sand as casting sand because it will have better flow ability and it will also need less binder [Ihom A et al 2011]. For local sand $C$, its particles were mostly roundedged. This makes sand $C$ had closer characteristic to sand $A$ than sand $B$. The particle morphology of sand $B$ particles itself were mostly composed of crystals and sharp-edged-angular particles. Crystal particles have poor performance because it has low compressive strength and need more binder to support its structure's green compression strength and it's forming ability, these will cause decrease in its flow ability and its permeability characteristic which will result in more defects in the casting product [Brown J, 1994].

\section{Characterizations of chemical elements and phase of quartz sand}

Material characterizations experiment (Table 3 and Figure 4-6) were conducted with XRD and XRF for all three samples. Silica sand has the advantages of common occurrence and abundance, ease of 
bonding with organic or inorganic binders, low cost, and the ability to be reclaimed for reuse by wet, dry, or thermal methods. Silica sand have characteristic to withstand high temperature, and ability to be recycle was high, because generally the structure of silica sand particle have resistant to deformation. It also possesses certain disadvantages when used in the production of metal castings. The major disadvantage of silica sand is its characteristic high thermal expansion. Silica sand mostly consist of silica oxside, which is usually resistant to high temperature but to balance this characteristic it is needed to expand when its exposed with high temperature which can be seen in figure 7 . This expansion causes casting quality problems and contributes to other expansion-related defects, such as crack and crumble mold. If the mixture of sand casting such as water and clay content as one of bonding agent not good, with expansion rate which occur during pouring molten metal, before the casting process is finished, crack or defect in the sand casting will possible hapened. Figure 7 illustrates the typical thermal expansion of various silica materials and depicts alpha quartz, the characteristic polymorph of silica sand, expanding at a constant rate until it reaches a temperature of approximately $573^{\circ} \mathrm{C}$ [Krukowsky, 2006]. As the temperature increases beyond this point, a sudden expansion takes place because of the change from alpha quartz to beta quartz. It happened because the energy which is obtained is used to change the phase of quartz from beta to alpha which is influenced in expansion of silica sand. High thermal expansion requires carefully controlled additions of cushioning materials (e.g., cellulose additives) to minimize the deformation and rupture of mold surfaces in contact with molten metal. Another disadvantage is that silica sand is unable to resist metal penetration and reactions that occur in quartz when in contact with casting surfaces.

Table 3. XRF analysis result

\begin{tabular}{|c|c|c|c|c|c|c|c|}
\hline \multirow[t]{2}{*}{ Element } & \multicolumn{3}{|c|}{ Weight percentage (\%) } & \multirow[t]{2}{*}{ Element } & \multicolumn{3}{|c|}{ Weight percentage (\%) } \\
\hline & $\begin{array}{c}\text { Sand } \\
\text { (A) }\end{array}$ & $\begin{array}{l}\text { Sand } \\
\text { (B) }\end{array}$ & $\begin{array}{l}\text { Sand } \\
\text { (C) }\end{array}$ & & $\begin{array}{l}\text { Sand } \\
\text { (A) }\end{array}$ & $\begin{array}{l}\text { Sand } \\
\text { (B) }\end{array}$ & $\begin{array}{l}\text { Sand } \\
\text { (C) }\end{array}$ \\
\hline $\mathrm{O}$ & 51.32 & 50.67 & 46.09 & $\mathrm{SiO}_{2}$ & 85.7 & 78.08 & $\begin{array}{c}55.1 \\
7\end{array}$ \\
\hline $\mathrm{Si}$ & 40.06 & 36.5 & 25.79 & $\mathrm{Al}_{2} \mathrm{O}_{3}$ & 4.54 & 13.87 & $\begin{array}{c}18.7 \\
6\end{array}$ \\
\hline $\mathrm{Al}$ & 2.4 & 7.34 & 9.93 & $\mathrm{Fe}_{2} \mathrm{O}_{3}$ & 1.68 & 2.62 & $\begin{array}{c}11.6 \\
8\end{array}$ \\
\hline $\mathrm{Fe}$ & 1.17 & 1.83 & 8.17 & $\mathrm{CaO}$ & 0.76 & 0.9 & 7.22 \\
\hline $\mathrm{Ca}$ & 0.55 & 0.64 & 5.16 & $\mathrm{~K}_{2} \mathrm{O}$ & 0.6 & 1.13 & 2.17 \\
\hline K & 0.49 & 0.94 & 1.8 & $\mathrm{MgO}$ & & & 1.39 \\
\hline $\mathrm{Mg}$ & & & 0.84 & $\mathrm{TiO}_{2}$ & 3.99 & 1.01 & 1.01 \\
\hline $\mathrm{Ti}$ & 2.39 & 0.6 & 0.6 & $\mathrm{P} 2 \mathrm{O}_{5}$ & 1.04 & 0.9 & 0.76 \\
\hline $\mathrm{Cl}$ & 0.53 & 0.59 & 0.43 & $\mathrm{SO}_{3}$ & 0.77 & 0.59 & 0.68 \\
\hline
\end{tabular}




\begin{tabular}{cccccccc}
\hline $\mathrm{P}$ & 0.45 & 0.39 & 0.33 & $\mathrm{Cl}$ & 0.53 & 0.59 & 0.43 \\
$\mathrm{~S}$ & 0.31 & 0.24 & 0.27 & $\mathrm{MnO}$ & 0.05 & 0.04 & 0.31 \\
$\mathrm{Mn}$ & 0.04 & 0.03 & 0.24 & $\mathrm{SrO}$ & & 0.01 & 0.09 \\
$\mathrm{Zn}$ & & & 0.04 & $\mathrm{ZrO}_{2}$ & 0.11 & 0.06 & 0.04 \\
\hline
\end{tabular}

These problems arise where there are reentrant angles in hot-spot areas of large iron and steel castings and, in Hadfield's austenitic manganese steel castings, when the steel contains high amounts of manganese that attack (or wet) the silica sand mold surfaces. While experimental measurements of $\mathrm{SiO}_{2}$ (Table 3) revealed the highest $\mathrm{SiO}_{2}$ content $(85.7 \%)$ was in sand sample A, the Ceper sand. Sand B was composed of $78.08 \% \mathrm{SiO}_{2}$, and sand $\mathrm{C}$ has the lowest content of $\mathrm{SiO}_{2}$ at $55.17 \%$. The higher the content of silica, the more refractory the sand (Arieef $\mathrm{M}$ bin $\mathrm{H}$ et al, 2018). The presence of impurities in sand such as $\mathrm{Fe}_{2} \mathrm{O}_{3}, \mathrm{~K}_{2} \mathrm{O}, \mathrm{CaO}$ reduced the silica content and lowered the ability of refractoriness and avoiding fusing in the casting process. Experimental results from the measurement using XRD (Figure 4-6) revealed that the $\mathrm{SiO}_{2}$ elements in these three types of sand are in quartz phase. In quartz phase, the sand morphology will not be deformed or undergone thermal shock and will have fast cooling property [Gazzano E F Di et al, 2016].

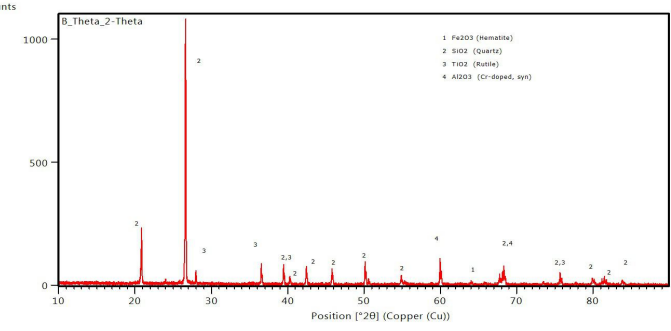

Figure 4. XRD analysis on sand $A$

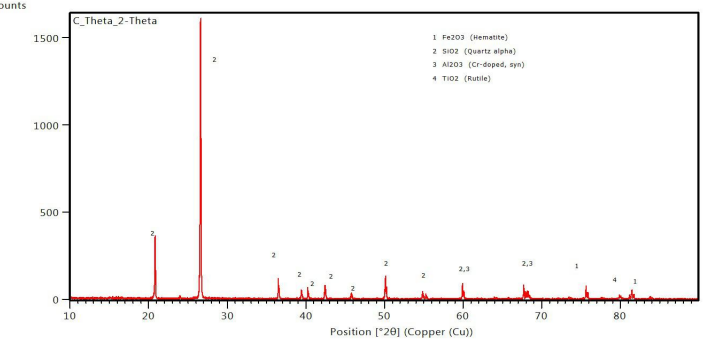

Figure 5. XRD analysis on sand B

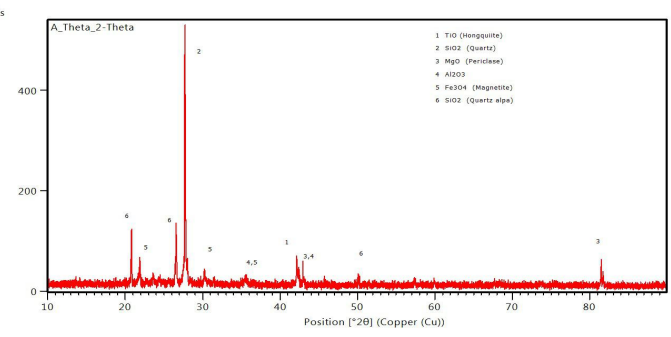

Figure 6. XRD analysis on sand $C$

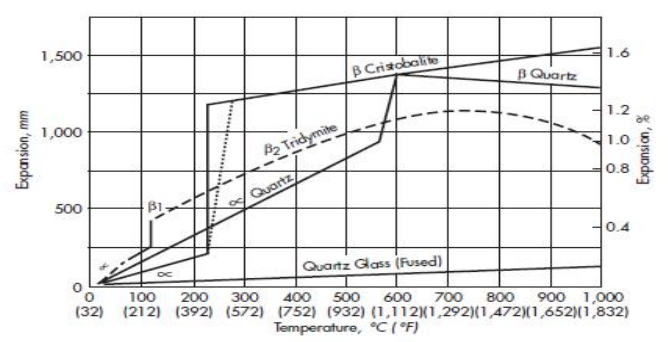

Figure 7. Thermal expansion of silica material

Experimental results from measurement using XRF and XRD (Table 3 , Fig 6 ) shows that only sand $C$ contained $1.39 \%$ MgO. $\mathrm{Mg}$ element is desired because it has the ability to increase the casting sand endurance in high temperature when the silica content in the sand is not high enough to endure the temperature [Carnin R L P et al, 2012]. In addition, sand $\mathrm{C}$ also had the highest $\mathrm{Al}_{2} \mathrm{O}_{3}$ 
content at $18.76 \%$, while Sand $A$ and $B$ only had $\mathrm{Al}_{2} \mathrm{O}_{3}$ content of $4.54 \%$ and $13.87 \%$ respectively. The existence of aluminum improves the form ability of casting sand, so that it can maintain its permeability and will reduce binder use [Carnin R L P et al, 2012]. The resulting surface defect and porosity caused by trapped air bubbles at metal pouring will also be minimized (Saikaew \& Wiengwiset, 2012). The Si element in the sand has a characteristic that contributed to the ability of casting sand to withstand high temperature, other than that $\mathrm{Al}, \mathrm{Mg}$, and $\mathrm{Na}$ elements contained in the casting sand also influences to some degree the casting endurance in the high temperature casting process (Carnin et al., 2012). Impurities such as $\mathrm{Fe}_{2} \mathrm{O}_{3}, \mathrm{~K}_{2} \mathrm{O}$ have a tendency to reduce the refractoriness of greensand [Brown J and John R, 1999]. From XRF result (Table 3 ), Sand $C$ have highest content of impurities of $\mathrm{Fe}_{2} \mathrm{O}_{3}, \mathrm{~K}_{2} \mathrm{O}$ at $11.68 \%$ and $2.17 \%$ respectively. While other have much less impurities content than sand $\mathrm{C}$. For sand $\mathrm{A}$ have $\mathrm{Fe}_{2} \mathrm{O}_{3}, \mathrm{~K}_{2} \mathrm{O}$ content of $1.68 \%$ and $0.6 \%$ respectively, and for sand $\mathrm{B}$ have $\mathrm{Fe}_{2} \mathrm{O}_{3}, \mathrm{~K}_{2} \mathrm{O}$ content of $2.68 \%$ and $1.13 \%$ respectively. The different of element content were influenced by the environment at each mining site. A forming process was influenced mostly with time. The longer of time required, it can affect the total content of each element. According to Brown, maximum limit for $\mathrm{Fe}_{2} \mathrm{O}_{3}, \mathrm{~K}_{2} \mathrm{O}$ content not exceeds $0.3 \%$ and $0.5 \%$ respectively. So in general these three samples still need further handling to reduce the impurities content. From XRF result (Table 3 ), $\mathrm{CaO}$ content for sand $\mathrm{A}$ at $0.76 \%$, and for sand $\mathrm{B}$ and $\mathrm{C}$ had $\mathrm{CaO}$ content of $0.9 \%$ and $7.22 \%$ respectively. The higher $\mathrm{CaO}$ content in the greensand, it will have a tendency to become more acid and it is not compatible with organic binder, also this will affect the amount of binder especially the consumption of resin for chemical bonded sand casting mold [Jain P, 2003; Webster $P, 1980]$. Based from XRF result, sand $B$ and $C$ are excel to sand $A$ because other than $\mathrm{Si}$, it also contained $\mathrm{Al}$ and $\mathrm{Mg}$ which will increase casting sand endurance in high temperature process.

\section{CONCLUSION}

From the results of the experiment, it can be concluded that Lampung local sand ( $B$ and $C$ ) can be used as casting sand alternatives for metal casting, especially for aluminum casting. Initial characterizations of local sands showed that Lampung local sand had better chemical elements composition than that of Javanese sand which could justify their potential as a better casting sand alternative.

\section{REFERENCE}

Abichou T, Benson C H, and Edil T B (2002), Micro-structure and Hydraulic Conductivity of Simulated SandBentonite Mixture," Clays Clay Miner., vol. 50, no. 5, pp. 537-545.

Agarwal R, Banga T, and Nanghnani T, (1981), Foundry Engineering. New Delhi: Khanna Publisher India.

Akuan A (2010) Teknik Pengecoran dan Peleburan Logam, First edit. Bandung: Universitas Jendral Ahmad Yani Bandung.

Arieef, A bin Abdullah, and R. bin Abdullah (2018), Physical and Chemical Properties of Perak River Sand for Greensand Casting Molds, Eng. Appl. New Mater. Technol., vol. 85, pp. $13-24$.

Bawa H S (2004), Manufacturing Processes - II, Manufacturing

Processes Mechanical engineering series, Vol 2, Tata McGraw-Hill Education.

Brown J (1994), Foseco Foundryman's Handbook 10'th edition, 10th ed. Birmingham: Pergamon Press PLC.

Brown J and John R., (1999) Sand and Greensand, Foseco Non - Ferrous Foundryman's Handbook, 11th ed. Oxford: Butterworth - Heinemann.

Carnin R L P, Valadares M, Raquel R, Leite S, Jorge C, and Dungan R S (2012), Thermochimica Acta Use of an integrated approach to characterize the physicochemical properties of foundry green sands, Thermochim. Acta, vol. 543, pp. $150-155$. 
Chastain S D (2003), Metal Casting: A Sand Casting Manual for The Small Foundry, First edit. Chastain Publishing, 2003.

Gazzano F. Di, E., Tomatis M., Turci F., Pardi L. A., Bronco S ., Fornaciai G., Innocenti M., Montegrossi G., Muniz M., Zoleo A., Capacci F., Fubini B., Ghigo D., and Romanelli M., (2016), Physico-chemical properties of quartz from industrial manufacturing and its cytotoxic effects on alveolar macrophages: The case of green sand mould casting for iron production, J. Hazard. Mater., vol. 312, pp. 18-27.

Heine R, Loper C Jr, and Rosenthal P (1967), Principles of Metal Casting 2nd edition, 2nd ed. New Delhi: Tata Mcgraw-Hill.

Ihom A, Agunsoye J, Anbua E, and Bam A (2009), The Use of Statistical Approach for Modelling and Studying The Effect of Ramming on The Mould Parameters of Yola Natural Sand, Niger. J. Eng., vol. 16, pp. 186-192.

Ihom A, Agunsoye J, Anbua E, and Ogbodo J (2011), Effect of Moisture Content on The Foundry Properties of Yola Natural Sand, J. Pract. Technol., vol. 19, pp. 85-86.

Ihom A, Suleiman V, and Nyior G, "Impact of Swelling Indices of Sakoto Clays in Sand Mixtures, J. Miner. Mater. Charact. Eng., vol. 11, pp. 1050-1054, 2012.

Jain P (2003), Principles of Foundry Technologies, 4th ed. New Delhi: Tata Mcgraw-Hill.

Jiang $J$ and Lin $X$, (2007), dimensional variations of Casting and Moulds in The Ceramics Mould Casting Process mater, Process Technol., vol. 189, pp. 247-255.

Krukowsky S T (2006), Foundry Sand, in Industrial Minerals and Rocks, Sevent Edi., J. E. Kogel, N. C. Trivedi, J. M. Barker, and S. T. Krukowski, Eds. Colorado: Society for Mining, Metallurgy and Exploration, Inc, p. 1434.

Kusdarto M S, Sukmawan, Andi Sutandi S, inventarisasi dan evaluasi bahan galian non logam di Kabupaten Lampung Tengah Dan Lampung Timur, Provinsi Lampung. Badan Geologi, Kementerian
Energi dan Sumber Daya Mineral. http://psdg.bgl.esdm.go.id. access Juli, 22nd 2019

Lavin P (2003), Asphalt Pavements : A Practical Guide to Design, Production and Maintenance for Engineers and Architects. CRC Press.

Meng $Y$ and B. Thomas B (2003), Modelling Transient Slag-layer Phenomena in the Shell or Mold Gap in Continous Casting, Metall. Mater. Transanction, vol. 34 B, pp. 707-725.

Moore D M and Reynolds R C Jr (1997), X- Ray Diffraction and The Identification and Analysis of Clay Minerals, 2nd editio. New York: Oxford University Press.

Mulyo A (2007), Potensi Bahan Galian Pasir Kuarsa Di Kecamatan Labuhan Maringgai Kabupaten Lampung Timur Provinsi Lampung, Bulletin of Scientific Contribution, Vol. 5 No. 2.

Saikaew C and Wiengwiset S (2012), Applied Clay Science Optimization of molding sand composition for quality improvement of iron castings, Appl. Clay Sci., vol. 67-68, pp. 26-31.

Saridikmen $H$ and Kuskonmaz N (2005), Properties of Ceramics Casting Molds Produced with Two Different Binders, Ceram. Int., vol. 31, pp. 873-878.

Simsir M, Kumruoglu L, and Ozer A (2009), An Investigation into Stainless Steel/ Structure-alloy-stell Bimetal Produced by Shell Mould Casting, Material, no. Desember, pp. 264-270.

Sudia T and Chijiwa K (1982), Teknik Pengecoran Logam, 4th ed, Pt Pradnya Paramitha, Jakarta.

Webster P (1980), Fundamentals of Foundry Technology. Redhill, Surrey: Port cullis Press.

Weiss D (2008), Advances in the Sand Casting of Aluminium Alloys, Fundamentals of Aluminium Metallurgy, Chapter 5, pp. 159-171.

Zrimsek A and Vinjas G (1961), Effect of Moulding Variables Parameters on The Properties of Clay Bonded Sands, Mod. Cast., vol . 39, p. 85. 
